\title{
A VIRÓTICA CONTAMINAÇÃO BURROUGHIANA NA LITERATURA DE FANZINE
}




\section{A VIRÓTICA CONTAMINAÇÃO BURROUGHIANA NA LITERATURA DE FANZINE}

Resumo:

Este estudo reflete acerca da origem e consolidação da técnica literária cut-up em uma manifestação literário específica, o fanzine. Também busca apresentar de que modo esta técnica pode funcionar como um mecanismo gerador de intertextualidades na (re)criação de textos presentes na arte do fanzine.

Palavras chave: Cut-up; Fanzine; Burroughs; Intertextualidade

\section{EL VIRAL CONTAMINACIÓN BURROUGHIANA EN LA LITERATU- RA DE FANZINE}

Resumen:

Este estudio reflexiona sobre el surgimiento y consolidación de la técnica literaria nombrada cut-up en una manifestación específica, el fanzine. También tiene como objetivo mostrar cómo esta técnica puede servir como un mecanismo que genera la intertextualidad en la (re)creación de los textos presentes en el arte del fanzine.

Palabras Clave: Cut-up; Fanzine; Burroughs; Intertextualidad

THE VIRAL BURROUGHIANA CONTAMINATION IN LITERATURE OF FANZINE

\section{Abstract:}

This study reflects on the rise and consolidation of literary technique cut-up in a specific literary manifestation, the fanzine. It also aims to show how this technique can work as a generating mechanism of intertextuality in the (re) creation of texts present in the art of the fanzine.

Keywords: Cut-up; Fanzine; Burroughs; Intertextuality 
"A vida é um cut-up. O que é a vida senão uma seqüência mais ou menos ilógica de acontecimento que não se prestam para fazer sentido?" William Burroughs

\section{INTRODUÇÃO}

Ao considerarmos que, segundo o teórico russo Mikhail Bakhtin, a língua é um elemento que não pode ser desvinculado do contexto social dos falantes, temos a noção de que a mesma é também fruto das relações sociais que estes estabelecem entre si. Nossa sociedade, ao se estruturar em grupos diferenciados possui consequentemente inúmeras manifestações literárias que representam a busca da singularidade e representatividade destes grupos sociais e culturais ${ }^{1}$, que através da criação de identidades discursivas e meios próprios de expressão buscam manifestar seus anseios. A singularidade desses meios são frequentemente uma opção (e alternativa) para artistas e escritores divulgarem seu trabalho, muitas vezes considerados à margem do mercado editorial.

No caso do fanzine, uma realidade social e cultural de um grupo específico constitui essa arte, revelando uma identidade que se reflete nesta produção informativo-artística, auxiliando na constituição da mesma. Este estudo ao direcionar-se para uma investigação acerca deste veículo de manifestação literária específica, pretende refletir sobre a origem e a consolidação da técnica literária designada cut-up, de modo a verificar como esta técnica pode funcionar como um mecanismo gerador de intertextualidades na (re)criação de textos encontrados em fanzines. Desse modo, é sobre a linguagem literária, e mais especificadamente as criações que tem como base a técnica cut-up que direcionaremos nossas reflexões, procurando também destacar como o conceito bakhtiniano de intertextualidade está presente na constituição destes textos.

Acreditamos que a reflexão acerca desta arte é pertinente para o desenvolvimento dos estudos literários pelo fato de que, além de serem escassas as investigações acerca dessa temática, que tem como corpus uma literatura considerada "à margem" em relação à canônica ², a literatura de fanzine também

1"O problema das relações entre linguagem e cultura é um dos mais complicados que existem. Pode-se primeiramente tratar a linguagem como um produto da cultura: uma língua em uso em uma sociedade reflete a cultura geral da população. Mas em outro sentido, a linguagem é uma parte da cultura; ela constitui um de seus elementos, [...]. Mas isso não é tudo: pode-se também tratar a linguagem como condição da cultura e por duas razões; é uma condição diacrônica, pois é, sobretudo por meio da linguagem que o indivíduo adquire a cultura de seu grupo; educa-se, instrui-se a criança pela palavra; Ela é criticada ou elogiada com palavras." (LÉVI-STRAUSS, 1957, p. 78-79)

2Entendemos por canônica obras que são valorizadas, ao mesmo tempo, em razão da unicidade de sua forma e da universalidade de seu conteúdo (COMPAGNON, 2001). 
está vinculada a um circuito editorial alternativo, possuindo, em decorrência disto, um valor diferenciado da maior parte das manifestações literárias que seguem uma lógica editorial mercadologicamente regrada³.

Dessa forma, apresentaremos, de início, os acontecimentos históricos e processos artísticos que levaram ao nascimento e consolidação da técnica literária do cut-up. Em um segundo momento, faremos algumas colocações acerca do veículo literário denominado fanzine e suas principais características e peculiaridades, reflexionando de que modo a técnica do cut-up revela-se nas produção desta arte considerada underground. Para finalizar, teceremos algumas considerações a respeito da noção de intertextualidade na arte do fanzine, gerada a partir da técnica do cut-up.

\section{E TUDO COMEÇOU COM A FILHA DAS REVOLUÇÕES ...}

Em meados do século XIX e início do século XX vinga o fruto da ascensão do racionalismo e das revoluções que transformaram o mundo: a modernida$\mathrm{de}^{4}$. Esta, trouxe consigo a sensação de perda da unidade do homem, levando a uma crise que, refletida no fazer artístico, teve como consequência a dessacralização da arte, com o fim do mito da criação e, em termos benjaminianos, da perda da "aura" tanto do criador como da criatura. As manifestações artísticas passam, a partir de então, a voltar-se para si mesmas, intervindo na realidade e apresentando críticas autorreferenciais.

Em relação à escrita ocorre uma verdadeira ruptura com a tradição poética até então estabelecida, pois, se antes a literatura era produzida com uma aparente ausência de "consciência crítica" por parte do escritor, sendo considerada fruto de "inspirações divinas", a partir das vanguardas artísticas, no século XX, tal noção desmorona e passa a dar lugar a outras, que por sua vez apresentam como cerne um fazer literário com maior criticidade, em que segundo Barthes (2004), o escritor questiona-se quanto ao seu ofício.

Se aceitarmos tal posicionamento, acordamos que foi com os modernismos e as vanguardas européias que a palavra poética "pura" "contaminou-se",

3 O fanzine, como um meio de propagação de discursos dissociados do meio acadêmico e científico, vincula uma literatura um tanto singular que, em uma sociedade voltada para o consumo desenfreado de bens (culturais) onde o comércio e a indústria editorial em parceria com a mídia em geral, direcionam vendas, gostos, e ideologias, acaba sendo muitas vezes tachada de "literatura marginal", por estar à margem desse mercado, como exemplo, temos as manifestações literárias surgidas nos anos 70/80 no Brasil.

4Aqui, utilizamos conceitos à maneira apresentada por Nestor Garcia Canclini em sua obra Culturas Híbridas: "Adotamos com certa flexibilidade a distinção feita por vários autores, desde Jürgen Habermas até Marshall Bermann, entre modernidade como etapa histórica, a modernização como um processo sócio-econômico que vai construindo a modernidade, e os modernismos, ou seja, os projetos culturais que renovam as práticas simbólicas com um sentido experimental ou crítico." (CANCLINI, 1998, p. 23). 
sendo a escrita tomada pela incorporação de inúmeros elementos cotidianos, além de contar com bruscas mudanças sintagmáticas, fonéticas e semânticas. É a partir destas mudanças que a literatura passa a interagir com outros elementos, com outras mídias, e as manifestações artísticas se hibridizam, estabelecendo entre si laços que culminam em novos objetos e discursos. Frente a isto, a escrita moderna caracteriza-se então pela presença de técnicas plurais que se afirmam ao tornar a literatura uma arte cada vez mais múltipla.

A arte de fanzine através da prática do cut-up, funde imagem e texto, apresentando um novo diálogo com produções artísticas, demonstrando também que a contemporaneidade da arte acentua tal hibridismo trazendo consigo inúmeras técnicas de escrita e produções discursivas que contam com a inserção de novas mídias (cinema, música, etc.) à literatura. A técnica cut-up, cuja fonte de alento partiu das artes plásticas, explicita o rompimento com a lineariedade textual em que o "corta e cola" de fontes ${ }^{5}$ e referências aparentemente desconectadas e sem relação lógica entre si, geram sentidos e "contra-sentidos" infinitos, e que, distanciados das fontes de origem se relacionam entre si adquirindo uma nova roupagem. Assim, a técnica passa a atender, potencializar, e em certa medida refletir, a fragmentação, (des)organização e sensibilidade de nossa sociedade.

\section{CUT - UP: O TRAMPOLIM DE UMA LINGUAGEM EM (DE) COMPOSIÇÃO}

“Linguagem é vírus."

Burroughs

Ao longo de toda a história da criação literária, inúmeros escritores sempre se apoiaram em invenções de técnicas (artifícios narrativos, recursos técnicos etc.) ${ }^{6}$ para a elaboração de seus escritos. Não somente na literatura, mas

5"Nessas "poesias" não se poupava o emprego de trechos das mais diversas procedências - da Bíblia a bulas de remédio -, a fim de alcançar a impressão de simultaneidade, típica da modernidade, em que cotidianamente somos bombardeados por avisos, anúncios, propagandas, diretrizes e demais mensagens diretas e subliminares. Essa cacofonia do mundo moderno, como sabemos, é produzida graças aos diversos meios de comunicação, como o rádio, televisão, alto-falantes, outdoors, panfletos etc." (PAULINO JÚNIOR. p.64, 2004) 6A respeito de técnicas de criação literária, José Paulino Júnior nos traz: "cito os célebres casos de Joyce e sua minuciosa criação de "case-words" - as "palavras-valise" -; Aldous Huxley e a técnica do "contraponto" narrativo, que influenciou o Érico Veríssimo de Caminhos cruzados; o "fluxo de consciência" - "stream of consciousness" - nas obras de Gertrude Stein; o "real maravilhoso" e a "linguagem neo-barroca", defendidos por Alejo Carpentier para a realização de uma literatura latino-americana essencialmente participativa; a "desmemorização" nos escritos de Virginia Woolf; assim como a atmosfera que J. G. Ballard institui por 
no cinema, na música e na pintura, a elaboração de um método ou técnica por parte do artista foi e continua sendo uma constante, que visa alcançar uma finalidade ou efeito específico no receptor da obra.

A respeito da técnica cut-up, apesar desta consolidar-se através das obras do escritor beat ${ }^{7}$ William Burroughs, em meados da década de 60, os dardos históricos nos apontam para a "gestação" da "técnica do recorte" na década de 1920, com as vanguardas artísticas. Desse modo, tal técnica tem suas raízes fincadas em manifestações artísticas de dois dos principais movimentos de vanguarda, o Dadaísmo e o Surrealismo (em especial a vanguarda Dadaísta de Tristan Tzara e sua sacola de recortes ${ }^{8}$ ), e buscou nos procedimentos e manifestações literárias destas vanguardas as bases para o seu desenvolvimento.

As vanguardas, ao insurgirem-se contra uma forma de expressão literária convencional, cunharam inúmeros métodos ${ }^{9}$ de criações alternativas, que questionaram e também colaboraram para a destruição da noção romântica de criação artística.

A respeito das criações artísticas dadaístas, Dante Tringali em seu estudo

meio do estilo que ele denomina "waking dreams": "[...] isto é, mostrar a realidade como se fosse um sonho, de modo que nada seja real e nos encontremos lançados em um universo onde tudo é imaginação ou pesadelo." ( PAULINO JÚNIOR, 2004, p.61)

7A Geração Beat foi delineada por Sérgio do Carmo em Culturas da Rebeldia (2000) do seguinte modo: “Desde o início dos anos 50, Allen Ginsberg, Jack Kerouac, William Burroughs e outros companheiros vinham despontando, em primeira instância, para um movimento poético e literário inédito- o beat. O termo significa não só a beatitude, beato, santificação, como também a batida do jazz, o embalo, o ritmo (usado também para expressar cansaço, saturação). Beat havia se tornado uma palavra mágica também para os jovens ingleses; lembrava a batida, o ritmo compassado. Daí ter originado o nome Beatles, uma fusão das palavras beat e beetles ("besouro"). O espírito de contestação induz esses jovens a se refugiarem numa suposta beatitude. O inconformismo da geração começa, a rigor, com On the Road ("Pé na estrada"), de Jack Kerouac (1922-1969), que colocava toda a moçada em movimento com seu relato de vida nômade. Escrito em 1951, Kerouac datilografou o texto freneticamente em um rolo de papel telex para evitar a constante troca de folha. A estrada simbolizava a viagem sem rumo como os conquistadores errantes do faroeste americano de outrora" (CARMO, 2000, p.28)

8Tzara propõe uma "Receita de poema dadaísta" que consiste em passos que devem ser seguidos: "Tomai um jornal e uma tesoura. Escolhei no jornal um artigo que tenha a extensão que quereis dar ao poema. Cortai o artigo e, em seguida, cortai as palavras que o formam e colocai-as num saquinho. Agitai docemente. Retirai as palavras, uma depois da outra e copiai -as nesta ordem. O poema está pronto. Não importa que ninguém entenda." (Tristan Tzara) 9De acordo com Dante Tringali foi no movimento Dadaísta que um grande número de artifícios de criações artísticas foram criadas. Dentre alguns, o autor nos traz o poema abstrato fantástico (poema composto por palavras inventadas pelo poeta, onde o som- sem sentidose sobressai), poema cancelado (há traços em lugar de palavras), poemas com jogos de palavras, e a o poema desconexo: "o poema desconexo, incoerente, produzido por uma associação livre de idéias disparatadas, de onde resulta um texto sem sentido, absurdo.” (TRINGALI, 1990, p.36) 
Dadaísmo e Surrealismo (1990) apresenta que esta andou de mãos dadas com o acaso, com aquilo que se configurava pela aleatoriedade. Na maior parte das técnicas utilizadas nas criações do movimento o jogo de palavras ocorria acidentalmente, como nos coloca o autor

A mais importante forma de composição se baseia na exploração do azar. A obra de arte se entende como produto do acaso, sem interferência psíquica, nem consciente, nem inconsciente. Pode-se escolher o processo de construção da composição, mas o resultado é imprevisível, um caos. Esse processo de composição se chama automatismo mecânico puro e constitui o traço mais característico e específico do dadaísmo, tendo sido proposto por Tzara num poema: Para Fazer um Poema Dadaísta. (TRINGALI, 1990, p.34)

Tristan Tzara ao propor (e concretizar) a ideia de aleatoriedade da criação literária, com um receituário nada convencional para a criação de poemas através de sacos plásticos e colagens, consagrou-se como o "avô" do cut-up, sendo William Burroughs, juntamente com Brion Gysin ${ }^{10}$ os "pais", e o método o "filho rebelde" do casal.

Desse modo, trinta anos mais tarde, em meados dos anos 60, em "laboratórios" nos subúrbios e submundos undergrounds londrinos e parisienses, Burroughs e Brion Gysin realizam seus experimentos literários. Historicamente, depois da sessão de hecatombes que abalaram o mundo, Brion Gysin (contando com a presença do acaso) ao revestir a superfície de uma mesa com papeis de jornais, juntamente com o parceiro de experimentos Burroughs, com o intuito de protegê-la, tem um momento eureka, pois na medida em que as camadas de jornais interagiam aleatoriamente e justapostamente entre si, iam dando margem a existência de um conteúdo implícito e originando a técnica da colagem que mais tarde recebe na literatura a denominação de cut-up ${ }^{11}$. Assim, os papais (des)construtores, ao beberem da fonte Dadaísta o líquido tzarista (alucinante) deram origem e propagaram o método.

Tal técnica que se propagou viroticamente a partir da publicação da trilogia burroughiana The Soft Machine (1961), The Ticket That Exploded (1962) 10Artista plástico, Brion Gysin nasceu nos arredores de Londres, em 1916, mudando-se para Paris em 1934, onde logo foi "acolhido" no grupo surrealista presidido por André Breton. 11Burroughs considera o fato de que "Toda escrita é de fato cut-ups. A colagem de palavras lidas escutadas super escutadas. $O$ que mais? $O$ uso de tesouras torna o processo explícito e sujeito a extensão e variação. Prosa clássica clara pode ser composta inteiramente de cut-ups rearranjados. Cortar e rearranjar uma página de palavras escritas introduz uma nova dimensão para a escrita possibilitando ao escritor converter imagens em variação cinemática. As imagens mudam de sentido sob as tesouras cheiram imagens para soar visão e soar som, para cinestesia. Aqui é onde Rimbaud estava indo com sua cor das vogais. E seu "sistemático desrregramento dos sentidos". O lugar da alucinação de mescalina: ver cores provar sons cheirar formas." (BURROUGHS, s/d, p.03) 
e Nova Express (1964), e de seu segundo romance intitulado de Naked Lunch (1959), visava primordialmente romper com os limites impostos pela escrita tradicional, recombinando fragmentos de um único ou mais textos de modo a resultar em quebras e alterações na ordem sintagmática, com a projeção de uma nova mensagem ${ }^{12}$. Burroughs para demonstrar o funcionamento da técnica, realiza suas primeiras experimentações com textos de Rimbaud e Shakespeare. Assim, a palavra ossificada, cristalizada nas amarras da sintaxe começa a liberta-se, sendo uma técnica anti-convencional utilizada com o intuito de obter novos discursos. Semelhante a receita tzarista, Burroughs apresenta o passo-a-passo da (des)construção da escrita:

"Pegue qualquer poeta ou escritor que você admira, digamos, ou poemas que você tenha lido muitas vezes. As palavras perderam significado e vida por anos de repetição. Agora pegue o poema e datilografe passagens selecionadas. Encha uma página com excertos. Agora corte a página. Você tem um novo poema. Tantos poemas quanto você queira." (BURROUGHS, s/d, p.02)

A literatura universal nos oferece diversos exemplos (de Joyce à Cortázar) que se valeram de tal técnica ${ }^{13}$ e cujos resultados literário foram autênticos e inovadores. Atualmente, um nome que tem se destacado na utilização desta técnica é Ricardo Piglia, escritor argentino que em sua obra romanesca intitulada Cidade Ausente (1993) utiliza relatos e fragmentos de outros textos em sua obra. Na cena brasileira de literatura contemporânea a influência da técnica mencionada se faz presente na produção da escritora curitibana Luci Collin em seu livro de contos intitulado Acasos Pensados (2008), que possui uma série de narrativas curtas com recortes e colagens de outros textos que integram a composição da obra.

Com tal técnica, o intervalo entre o significante e o significado amplia-se de modo que a relação entre estes dois elementos, considerados em um contexto específico de inserção das palavras, culmina inúmeras vezes em um não-sentido ${ }^{14}$. Segundo Jamer Guterres de Mello, no estudo

12“Em sua forma inicial e simplificada, o cut-up era realizado em uma página inteiramente datilografada com um texto linear, que era cortado em quatro partes iguais, com um corte horizontal e um vertical na folha. De acordo com o escritor, a recombinação dos quadrantes resultava em surpreendentes e inovativas composições, quando a peça era novamente datilografada e no processo as palavras e frases truncadas eram corrigidas e recriadas."(SOUZA, 2011, p.02)

13Influenciando não só a produção literária, a técnica também se estendeu em composições musicais de artistas como David Bowie e Kurt Cobain. No cinema o cut-up esteve presente em produções fílmicas sob a direção de Jean-Luc Godard, e sob a técnica kuleshov, que se aproxima muito técnica de montagem do cut-up, por exemplo.

14A respeito dos "não-sentidos" muitas vezes gerados pela técnica, Jamer de Mello afirma que o intuito da mesma é: "destroçar a linguagem e fazê-la seguir por uma linha revolucionária nômade arrancando de sua própria expressão outro sentido, talvez um não-sentido, um 
intitulado Insensato: um experimento em arte, ciência e educação (2010)

O método cut-up tem como objetivo produzir um pensamento efetivado por imagens, por processos analógicos, utilizando corte e colagem tanto em textos escritos quanto em gravações de áudio ou filmagens, em detrimento do circuito lógico-sintático imposto como primeira instância reflexiva pela linguagem. (MELLO, 2010, p.20)

Ademais de um jogo com palavras, o cut-up é uma técnica artística que propõe a inovação na forma de criação literária, trabalhando com a noção de fragmentação e criação de imagens instantâneas, que conta com uma leitura não linear, apresentando deslimites ao leitor que, na interação com o texto se torna também cúmplice e agente.

Frente a isto, podemos inferir que o criador da técnica (ou the cutter) não pretende manter algum "domínio, controle ou direção" sobre a sua criação, pois, é uma técnica de composição na qual o os movimentos da sua "criatura" ficam lançados à sorte, ao acaso. As frases, as orações, e palavras, muitas vezes tiradas de textos consagrados, são deslocadas de seu contexto "original" e lançadas em outro, e outras frases de inúmeras fontes são datilografas, recortadas e dispostas aleatoriamente em um fanzine.

Concernente a isso, segundo Burroughs "O corte e o rearranjo de uma página de palavras escritas introduz uma nova dimensão à escrita habilitando o escritor a modular as imagens numa variação fílmica" (p.34), ou seja, esta técnica de justaposição de palavras leva o receptor a ter reações de estranhamento diante do texto tramado (ou melhor recortado/colado), onde a percepção sobre o material ultrapassa as fronteiras do "convencional".

Nesse sentido, a criação literária embasada na técnica burroughiana se constrói com a disposição e justaposição de alucinadas e iluminadas frases que entram na dança, buscando seu lugar na pista e seu par, para enamoradas, gestarem o ritmo, a prosa e a poesia, que no movimento da dança frutificam orações, frases, pontos, parágrafos, enfim, uma literatura que tem origem na coreografia das palavras soltas que assinam seu divórcio com a autoridade sintática e também autoral.

\section{FANZINE : UM HOSPEDEIRO ACOLHEDOR}

Burroughs, para caracterizar o poder de propagação e destruição que a linguagem possui, utiliza a metáfora do vírus: para ele, a linguagem é como um vírus, e como tal, necessita de um hospedeiro, de outro elemento vivo para se instalar. Desse modo, afora da "literatura consagrada", o "quebra-cabeça" burroughiano influenciou narrativas "menores" e produções alternativas, nas nonsense. A falta de sentido pode conter sentidos infinitos" (MELLO, 2010, p. 20) 
quais o vírus também se hospedou, encontrando um habitat no qual conseguiu desenvolver-se com sucesso. Eis que a técnica do cut-up, através de seus "textos-montagens", encontra o mundo underground com a literatura de fanzines. O termo fanzine vem da aglutinação do termo inglês fanatic (fã) somado à magazine (revista), "revista de fã" que nasce em meados dos anos 30 nos EUA em publicações organizadas por fãs do gênero de ficção científica ${ }^{15}$, e em meados da década de 60 no Brasil, tendo alcançado grande popularidade no país nos anos 80, segundo nos apresenta Magalhães (1993). Uma revista que surgiu da necessidade que alguns fãs (de música, quadrinhos, etc.) de expor suas ideias, expressarem e vincularem sua arte e ideologias.

Conservando uma postura de resistência frente ao mercado e ao projeto editorial, com a criação e difusão de uma cultura à margem dos circuitos oficiais da cultura impressa, a arte de fanzines é um expressão artística considerada por muitos como amadora, sendo geralmente vinculada à expressão cultural de grupos contra-culturais, que cumpre ao mesmo tempo uma necessidade individual e coletiva.

É um meio de expressão que, distante da grande imprensa (editoras, livrarias, bibliotecas) não é massificado ideológica e mercadologicamente, sendo assim um espaço único de concretização da arte undergorund, que não necessita do aval de censores e editores. Assim, podemos considerar que os fanzineiros são "porta-vozes" de uma (contra)cultura alternativa e independente, que segue o lema do it yourself- D.I.Y (faça você mesmo) onde a motivação principal dos escritores é a liberdade de expressão e a atitude do criador em manifestar para seus comuns os mesmos valores, gostos e ideologias.

Segundo o estudioso do assunto Jamer de Mello, o fanzine e seu mecanismo de criação e circulação funciona como

uma espécie de terrorismo poético -arte amadora e anti-autoritária, não calcada na eficiência mercadológica e sim na vontade de se manifestar- em detrimento de um terrorismo semiológico- onde o importante seria decifrar o mundo dos signos, nem sempre aptos a decifração. (MELLO, 2010, p.28)

Nesse ritmo, pelo fato de não pretender a inserção na produção de mercado, a arte do fanzine não possui grande número de tiragens, sendo o custo de sua produção baixíssimo ou quase nulo. Assim, conta com uma lógica e funcionamento interno: a ação de recortar, fotocopiar e passar adiante (seja de mão em mão, seja através de via postal) revela a formação de um público leitor

15Em sua origem, a ficção-científica era tratada como subliteratura, sendo renegada pelos circuitos oficiais. A forma que os amantes desse gênero literário encontraram para divulgar os seus trabalhos foi criar suas próprias publicações, editando boletins e magazines para circular entre os outros fãs. Dessa maneira surgiram os Fanzines, cujo primeiro que se tem notícia foi The Comet, criado em maio de 1930, por Ray Palmer, para o Science Correspondence Club. (MAGALHÃES, 2003, p.57). 
diferenciado, geralmente formados por jovens que se aproximam desse veículo literário por afinidade ideológica e com o intuito de manifestar o que considera importante para si e para os leitores, sem qualquer limitação (apenas a de seu criador) quanto à forma e conteúdo do mesmo.

Quanto às características formais, os fanzines eram tradicionalmente escritos à mão, ou datilografados ${ }^{16}$, ou seja, contavam com técnicas pouco aprimoradas (como os mimeógrafos, por exemplo). Porém, com o advento e maior acessibilidade ao computador, a editoração e o design da arte sofreu inúmeras mudanças e hoje, grande parte dos fanzines que circulam são digitados, de modo que são utilizados fotocópias e impressoras, o que gera muitas vezes uma arte considerada por alguns como "limpa" em relação aos criados manualmente ${ }^{17}$. Outra característica do fanzine é a atitude anti-copyright ${ }^{18}$ que possibilita além do intercambio de textos e troca de materiais entre os editores, a cópia livre das revistas. Geralmente ocorre um autofinanciamento da arte por parte do fanzineiro, que conta também com a ajuda do próprio público leitor, já que o objetivo do fanzine não é de cunho econômico.

Em relação às temáticas vinculadas na arte de fanzine, com a propagação do mesmo na década de 60 (no Brasil) diversas temáticas foram incorporadas, desde quadrinhos, poemas, música, política, literatura, pacifismo, ecologia, artes em geral, anarquismo, e até mesmo assuntos relacionados à moda, transformando-se além de um meio de divulgação, em um veículo de críticas e experimentação artísticas. Nos últimos anos muitos estudos têm sido realizados acerca do fanzine enquanto procedimento didático em sala de aula, com intuito de, além de outros motivos, estimular a criatividade dos docentes.

Dessa maneira, a criação da revista fanzine tem como base a total liberdade de inventividade e desse modo, a técnica cut-up que está à serviço do "desengaiolamento" de palavras e imagens, encontra na arte do fanzine um meio profícuo para desenvolver-se. Pelo fato de tal técnica por em evidência o "pecado" da "livre criação artística", ela trouxe consigo o debate sobre a questão dos direitos autorais e autoria de uma forma geral. Os textos "montados" não estão "protegidos" uns dos outros, mas estão em constante mudança, transformação, são textos que se cruzam.

Para Barthes, o texto literário é "um espaço de dimensões múltiplas, onde se casam e se contestam escritas variadas, nenhuma das quais é original: o texto é um tecido de citações, saídas dos mil focos da cultura" (2004, p.52). 16 Técnica do cut-up é encontrada no Fanzine Dalí, onde fragmentos textuais datilografados estão dispostos de modo aleatório.

17 Para maiores detalhes com relação às transformações na estética do fanzine indicamos o estudo de Henrique Magalhaes "A MUTAÇÃO RADICAL DOS FANZINES” (2003).

18Debate atual nas mais diversas mídias, a questão da autoria e dos direitos autorais tem gerado a formação de grupos que se posicionam contra ou a favor de tais direitos de cópia. Discussão interessante é a realizada pelo grupo Creative Commons: http://www.creativecommons.org.br/index.php?option=com_content\&task=view\&id=42\&/temid=80, Acesso em 22/02/2112. 
Acordando com Barthes, toda a literatura pode ser considerada como uma sobreposição, justaposição, colagem-recorte de palavras já escritas e ouvidas, como um deslocamento de fragmentos textuais que reorganizados se reincorporam à outros contextos, à outras redes significativas, provocando mudanças nelas em si e nas redes com as quais interagem.

Assim, a utilização da técnica do cut-up na arte de fanzine pode ser explicada, tanto pela experimentação técnica, quanto pela total subversão de uma rigidez gramatical conferida à língua, de modo que a técnica encontra nessa arte underground um meio onde frutifica sem estorvos ou empecilhos maiores, sendo respeitada pelos leitores e admirada por aqueles que com ela se deparam e buscam (ou não) possíveis entendimentos e significações nos "textosmontagens".

\title{
5 PINCELADAS ENTRE A INTERTEXTUALIDADE, O LEITOR E A NOÇÃO DE AUTORIA
}

\author{
"Cada enunciado é pleno de ecos e \\ ressonâncias de outros enunciados".
}

Bakhtin

Ao acreditamos que, na literatura, nada é totalmente inédito, e que de algum modo tudo já foi escrito, nos calcamos na ideia de que as construções discursivas são, de certo modo, bricolagens ${ }^{19}$ de outros discursos, e que a criação literária se vincula à noção de (re)produção a partir de um discurso já estabelecido por outrem. Nesse sentido, a literatura em geral, independentemente da época e do contexto histórico de produção, carrega consigo discursos intertextuais que fundem fontes distintas.

No final do século XIX o cruzamento de áreas diferenciadas dos saberes linguísticos e literários deram origem aos primeiros estudos de Literatura Comparada. Nesta, a noção de intertextualidade é tratada de modo muito amplo e tem suscitado debates e discussões profícuas para a área. Um dos estudiosos que se debruçou com mais afinco na questão do diálogo que as várias vozes de um único texto realizam entre si, foi Mikhail Bakhtin, que partindo de estudos relacionados ao gênero romanesco (em Dostoievski e Rabelais) cunhou o ter-

19Utilizamos aqui o conceito de bricolagem associado aos processos de criação, em que segundo Paola Jaques (2001) “Bricolar é, então, ricochetear, enviezar, zigue-zaguear, contornar. O bricoleur, ao contrário do homem das artes (no caso, o arquiteto), jamais vai diretamente a um objetivo ou em direção à totalidade: ele age segundo uma prática fragmentária, dando voltas e contornos, numa atividade não planificada e empírica (p.24) que consiste em uma "arquitetura do acaso, do lance de dados, uma arquitetura sem projeto" (p.25). 
mo intertextualidade ${ }^{20}$, que apresenta a noção de interação existente entre o "eu" e o "outro" (ou outros) em um texto.

O conceito de dialogismo (vozes dos narradores e personagens) bakhtiniano expõe, como a própria nomenclatura já adianta, a noção de que em um texto literário é composto de inúmeras vozes ${ }^{21}$ que se "alojam" e coexistem no interior de um texto, e que são percebidos de modo explícito (paródia, citação, plágio) ou implícito, realizando sempre um diálogo entre si. Para Bakhtin, "o discurso citado é visto pelo falante como a enunciação de outra pessoa, completamente independente na origem, dotada de uma construção completa, e situada fora do contexto narrativo" (1997, p.144).

Compartilhando das noções bakhtinianas a teórica Julia Kristeva (1978) apresenta que um texto "(...) nunca é um ponto (no sentido fixo), senão um cruzamento de superfícies textuais, num diálogo de vários escritos, o do escritor, o do destinatário, o do personagem, o do contexto cultural anterior e o actual" (KRISTEVA, 1978, p.188). De acordo com a autora todo e qualquer escrito deve ser visto como um conglomerado de outros textos, outras referências, e não algo "puro".

Unido a isso, a questão que nos interessa aqui é a de como os conceitos de dialogismo e intertextualidades apresentados, vão ao encontro da técnica do cut-up utilizada na arte do fanzine. Diante deste questionamento, devemos considerar também que para Julia Kristeva (1979, p.23) o texto é um "mosaico de citações" que se constitui pela transformação de um texto em outro. Destarte, a prática da colagem parte da apropriação de fragmentos textuais de outras obras, que realizada pela prática cut-up vai ao encontro da pura imaginação e o automatismo do the cutter (e aqui fanzineiro) que comandam o processo de criação onde várias vozes se entrecruzam.

$O$ literal recorte de fragmentos discursivos de fontes diversas revela que os discursos de outrem podem ser cominados de diversas maneiras, em especial pelos recursos gráficos: letra em foram itálica ou em negrito, por exemplo, e mais comumente com a utilização das aspas. Nesses casos se mantém pelo fanzineiro a identidade dos discursos (sem qualquer tipo de preocupação ou autoritarismo por parte do autor) na sua construção/montagem literária, o que não anula ao mesmo tempo a autenticidade da construção do novo texto.

Porém, ao considerarmos que na arte de fanzines o intuito maior é a subversão dos princípios de autoria da língua, a conservação das fontes originais de letras dos fragmentos anexados, além de ter um propósito estético e visual, também expõe a questão de "despreocupação" com a "conservação" da autoria dos fragmentos que, neste caso, são totalmente impessoais, com exceção das vezes em que se tem o propósito de fixar a ideologia do outro, como voz de autoridade. Colaborando com essa visão, Jamer de Mello assinala que

20Noção literária discutida com em meados dos anos 60/70 por inúmeros teóricos que tiveram como primeira fonte de reflexão os estudos de Bakhtin, no século XX.

$21 \mathrm{O}$ autor também denomina tal ajuntamento de vozes de polifonia. 
subverter o conceito de autoria fazendo da produção anterior uma fabricação, uma construção, de um espaço novo, onde o real e o imaginário são indiscerníveis. Justapor a ideia alheia em pequenos fragmentos desconexos, produzindo um texto novo. Não existe mais autor, existem apenas linhas, blocos, movimentos. Matéria pronta para ser mastigada e cuspida, recortada e colada. Linhas de fuga entre letras, palavras e frases surrupiadas, corrompidas, metamorfoseadas. Com efeito, o gaguejar como procedimento, ou seja, não é necessário partir de uma origem e chegar a um objetivo, mas, antes disso, estabelecer-se entre, ou ao lado desta passagem. Quebrar o percurso. (MELLO, 2010, p.48)

A noção de autoria é assim (in)diretamente posta em xeque por Burroughs, não somente pelo fato do escritor não possuir o controle do seu escrito, mas em razão das diversas fontes que na maioria das vezes são utilizadas na construção literária. Nesta direção, Barthes em sua obra S/Z aponta que

Un texto multivalente sólo cumple hasta el final su duplicidad constitutiva si subvierte la oposición de lo verdadero y lo falso, si no atribuye sus enunciados (aun con la intención de desacreditarlos) a autoridades explícitas, si le falta al respeto al origen, a la paternidad, si destruye la voz que podría darle al texto su unidad (<<orgánica>>); en una palabra si suprime sin piedad, fraudulentamente, las comillas que, según dicen, deben con toda honradez, encerrar una cita y distribuir jurídicamente la posesión de las frases entre sus respectivos propietarios (...). Se trata de atravesar el muro de la voz para llegar a la escritura: ésta rechaza toda designación de propiedad" (BARTHES, 2004, p.36)

Há uma total desestabilização e aniquilamento das identidades e origens dos enunciadores de tais discursos. O discurso que é construído a partir da incorporação do discurso do outro (ao seu próprio discurso, ou ainda no de outrem) apesar de deixar marcas do primeiro no segundo, estes acabam por se dissolverem um no outro, gerando outra composição. Ainda acordando com Jamer de Mello

Não importam os significados e procedências dos materiais de origem, apenas o que deriva de sua associação, o resultado final tal qual ele se apresenta após o processo de corte e colagem, tanto no caso de textos como imagens (MELLO, 2010, p.29).

Esteticamente vemos que esta nova dimensão de escrita abrange o processo de "artesania" e transformação de fragmentos textuais pelo the cutter, que os manuseia, corta e cola (aleatoriamente ou intencionalmente). Com rela- 
ção a isto, segundo Tringali, neste tipo de arte que emprega técnicas do "acaso"

"não se percebe sempre com clareza se o resultado provém de uma elaboração consciente ou inconsciente. O típico poema dadaísta deve ser consciente, automatizado, mecânico, abstrato. Neste caso, Tzara doutrina que o "pensamento se forma na boca". Mas diante de um grande número de poemas, hesitamos se não foi composto sob o ditado do inconsciente. Efetivamente, aqui se encontra a passagem da composição dadaísta para surrealista, esta última totalmente inconsciente, automática, não mecânica, antes hermética que abstrata, difícil mas interpretável. (TRINGALI, 1990, p.36)

A técnica do cut-up, ao partir da junção de fragmentos escritos de: jornais, revistas, bulas, artigos, letras de canções e etc. faz com que a linguagem seja recriada e com que a noção de propriedade autoral da escrita seja ignorada, sendo os discursos criados/montados encarados de forma independente dos quais tiveram origem, ainda que suas características próprias se manifestem em forma de "ruídos" no corpo do texto final, gerando por sua vez estranhamentos ao leitor ${ }^{22}$. Quanto a este elemento do fazer literário (o leitor), o mesmo deve trabalhar com a decifração dos códigos linguísticos inseridos em um contexto que, além da escrita, apresenta elementos pictóricos, como imagens e recortes diversos que devem ser analisados conjuntamente para a formação de significações. Dessa maneira, a literatura de fanzine nos permite que averiguemos uma pluralidade de vozes que dialogam entre si, trazendo até mesmo o diálogo com outras linguagens.

Assim sendo, a literatura de fanzine solicita um leitor ativo, que não se afaste ou se "escandalize", mas que embarque nesta viagem estética pela busca de uma literatura sem amarras, onde o leitor tenha que tatear o seu espaço em meio a arquiteturas em ruínas e escombros de palavras. De tal modo, poderíamos nos aprofundar na questão da recepção da arte de fanzines produzidos sob a técnica do cut-up, porém, o intuito deste trabalho foi gerar uma reflexão acerca de como esta técnica encontrou na arte do fanzine um espaço que possibilitou frutificar, espaço em que as palavras embaralhando-se entre si, se desnudam entre infinitas combinações que latejam a espera de um recorte, de

22 Segundo Souza (2011) em seu estudo intitulado Uma análise da palavra como agente parasitário na literatura de William Burroughs, o escritor inglês: "Em entrevista ao poeta e tradutor brasileiro Rodrigo Garcia Lopes, em 1992, Burroughs explica que depois de vários anos tentando usar exclusivamente o cut-up voltou ao que ele chamava de "literatura convencional", por perceber a dificuldade em "treinar" os seus leitores na leitura de suas obras. E reconhece que toda escrita "é de fato um cut-up, uma colagem de palavras lidas, ouvidas entreouvidas" e que os cut-ups foram "um beco sem saída, literalmente falando. Eles nunca tiveram a intenção de substituir a narrativa, mas de suplantá-la". (SOUZA, 2011, p.03) 
uma nova ligação que as possibilite interagir anarquicamente com outras, em uma verdadeira explosão e desconstrução com a sintaxe da língua.

\section{CONSIDERAÇÕES}

Assim, observamos no decorrer deste trabalho que, a palavra, ao desdobrar-se na técnica do cut-up produz, como um elemento virótico, reações em seu hospedeiro (neste caso a arte do fanzine), tomado pela parasita. Investigamos que a ocorrência desse vírus neste hospedeiro provoca infinitas reações, possibilitando a explosão de atribuições de significações às palavras que, por sua vez, se propagam em imagens ilimitadas em uma ação doentiamente virulenta de embaralhar sintagmaticamente e extrapolar a lógica da constituição das frases dentro do discurso, assim como da conexão lógica das frases entre si. Enfim, uma poética que na arte da composição visa à originalidade, sem pretensões de representação de beleza, verdade e mímese, mas que prima pela experimentação livre de convenções e modelos em prol das experiências estéticas. Analisamos também, que o fanzine, ao ser um veículo de comunicação literária anarquicamente experimental possibilita que a arte técnica do cut-up se desenvolva com grande presença. Ademais, tivemos a oportunidade de verificar que tal técnica também pode ser analisada sob uma óptica linguística em que os fragmentos textuais deram vazão as inúmeras vozes, a polifonia discursiva proposta por bakthin.

Nessa perspectiva, e para finalizar nosso estudo, trazemos Morelli, a voz do alter-ego do escritor Julio Cortázar na obra O jogo da Amarelinha (1963), que assim como o the cutter, almeja uma literatura "que não seja pretexto para a transmissão de uma mensagem", pois, "Não há uma mensagem, há mensageiros, e isso é a mensagem, assim como o amor é o que ama". (CORTÁZAR, 2010, p.79)

\section{REFERÊNCIAS}

BARTHES, Roland. O rumor da língua. São Paulo: Martim fontes, 2004. . S/Z, Buenos Aires: Siglo XXI editores argentina S.A, 2004.

BAKHTIN, Mikhail. Marxismo e Filosofia da Linguagem. $8^{\mathrm{a}}$ ed. Trad. Michel Lahud e Yara F. Vieira. São Paulo: Hucitec, 1997.

BURROUGHS, William, 0 método do cut-up. Tradução de Ricardo do texto da página de Burroughs no site da S Press. Disponível em <http://www.eulalia.kit.net/textos/burroughs. pdf.> Acesso em 15/02/2012.

CANCLINI, Nestor García. Culturas híbridas: estratégias para entrar e sair da modernidade. Tradução de Ana Regina Lessa e Heloísa Pezza Cintrão. São Paulo: Edusp, 1998, p. 23). CARMO, Paulo Sérgio do. Culturas da Rebeldia: a juventude em questão. São Paulo: SENAC, 2000.

CORTÁZAR, Julio. O jogo da Amarelinha, Ed: Civilização Civilização Brasileira, 1999. 
COMPAGNON, Antoine. O Demônio da Teoria: literatura e senso comum. Belo Horizonte: Editora da UFMG, 2001.

JACQUES, Paola B. Estética da ginga: a arquitetura das favelas através da obra de Hélio Oiticica. Rio de Janeiro: Casa da Palavra, 2001.

KRISTEVA, Julia. La Révolution du Langage Poétique. Paris, Seuil. 1978.

LÉVI-STRAUSS, C. Tristes Trópicos. Tradução de Wilson Martins, Ed. São Paulo: Anehmbi, 1957.

MAGALHÃES, Henrique. O que é fanzine. São Paulo: Brasiliense, 1993.

MELLO, Jamer Gutteres de. Insensato: um experimento em arte, ciência e educação. Porto Alegre, Dissertação (mestrado em educação). Universidade Federal do Rio Grande do Sul. Porto Alegre, 113f. 2010.

TRINGALI, Dante. In: Revista Itinerarios $\mathrm{n}^{\circ} 1$ UNESP, 1990. Disponível em <http://seer.fclar. unesp.br/itinerarios/article/view/1236/1004> Acesso em 15/02/2012.

PAULINO JÚNIOR, José. $O$ cut-up em Naked Lunch de William Burroughs : a narrativa em estilhaços. Dissertação (Mestrado em Letras) - Faculdade de Ciências e Letras, Campus de Assis, Universidade Estadual Paulista.147f, 2004.

PEREIRA, C.A. Messender. O Que é Contracultura. São Paulo: Brasiliense, 1986.

SOUZA, Alesxandre Adir. Uma análise da palavra como agente parasitário na literatura de William Burroughs. XII Congresso Internacional da ABRALIC- UFPR, Curitiba, 2011.

\section{Luciane Bernardi de Souza}

Acadêmica do curso de Letras Português e Literaturas de Língua Portuguesa e Letras Espanhol e Literaturas de Língua Espanhola pela Universidade Federal de Santa Maria. 